\title{
Performance of Sesame (Sesamum indicum L.) Under Different Supplementary Irrigation and Nitrogen Fertilizer Levels in Humera, Northern Ethiopia
}

ISSN: 2637-7659

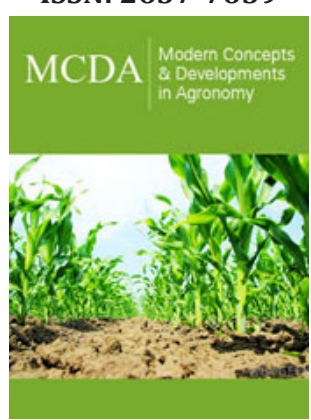

*Corresponding author: Abadi Berhane Girma, Department of Plant Sciences, College of Agriculture, Aksum University, PO. Box: +251314 , Ethiopia

\section{Submission: 啙 August 20, 2019}

Published: 僵September 11, 2019

Volume 5 - Issue 1

How to cite this article: Abadi Berhane Girma. Performance of Sesame (Sesamum indicum L.) Under Different Supplementary Irrigation and Nitrogen Fertilizer Levels in Humera, Northern Ethiopia. Mod Concep Dev Agrono.5(1). MCDA.000605.2019.

DOI: 10.31031/MCDA.2019.05.000605

Copyright@ Abadi Berhane Girma, This article is distributed under the terms of the Creative Commons Attribution 4.0 International License, which permits unrestricted use and redistribution provided that the original author and source are credited.

\author{
Abadi Berhane Girma* \\ Department of Plant Sciences, Ethiopia
}

\begin{abstract}
Field experiment was conducted in Humera in 2015 main cropping season in a factorial randomized complete block design (RCBD) to study the performance of sesame under different supplementary irrigation applications and nitrogen fertilizer rates. The study consists of four levels of nitrogen fertilizer rates ( $0 \mathrm{~kg} \mathrm{~N} 2 / \mathrm{ha}, 23 \mathrm{kgN} 2 / \mathrm{ha}, 37.5 \mathrm{kgN} 2 / \mathrm{ha}$ and $46 \mathrm{kgN} 2 / \mathrm{ha}$ ) and three levels of supplementary irrigation; rain-fed (I0), four irrigations (I4), and six irrigations (I6). Nitrogen fertilizer was applied in two splits, with the first half at sowing and the remaining half 30 days after emergence. Data on plant height, number of capsules per plant, number of seeds per capsule, thousand seed weight, harvest index, aboveground biomass and grain yield were recorded. The analysis of variance (ANOVA), in indicated that application of nitrogen fertilizer significantly $(\mathrm{p}<0.05)$ affected sesame grain yield. The highest grain yield $423.4 \mathrm{~kg} /$ ha, and $455 \mathrm{~kg} / \mathrm{ha}$ was obtained from application of $46 \mathrm{~kg}$ nitrogen per hectare, and six supplementary irrigation. The results obtained in this experiment showed that, application of supplementary irrigation could be an important climate change adaptation strategy in areas where onset and cessation of rainfall occur.
\end{abstract}

Keywords: Sesame; Nitrogen fertilizer; Supplementary irrigation Grain yield; Humera

\section{Introduction}

Sesame (Sesamum indicum L., $2 \mathrm{n}=26$ ) is the most ancient oilseed crop known and used by man [1]. It is the most important oilseed crop in Ethiopia. Sesame belongs to the Pedaliaceae family, which is adapted to hot areas [1] (Thakur, 1975). It is annual plant with broad leaves 2.5-5cm long, white, bell shaped inflorescence, with seeds of white, yellow, brown or black color [2]. It has a nickname 'Queen of oil seeds' due to its high quality polyunsaturated stable fatty acid. The stability of its oil is related to the polyunsaturated fatty acids reducing oxidative rancidity [1] (Balasubramanian \& Palaniappal, 2011) and the presence of natural antioxidants sesamol and sesamolinol [3]. Sesame is produced as a cash crop. It can be used for home consumption, but in addition to its oil for food, its byproduct oil cake, is an important animal feed. In Ethiopia, farmers used to burn the stalk after threshing, recently it is becoming an important raw material for different industrial purposes. Sudan is the major sesame producer in Africa followed by Nigeria, Somalia, Uganda and Ethiopia. In Ethiopia, sesame is very expensive, especially, due to its demand as a cash crop, for food and animal feed when compared with other oil crops. Sesame, sunflower, safflower, linseed and Niger seed are the most common oilseed crops in Ethiopia. Sesame is the second most agricultural export commodity in Ethiopia, next to coffee in annual export earning contributing about $14 \%$ of the total world export (Monitor Group 2012). Due to the increase in price, production of sesame is increasing in Ethiopia. Ethiopia's export share 1.5\% in volume and $1.9 \%$ in value to the World market in 1997, had grown to $8.9 \%$ and $8.3 \%$ in 2004 respectively [4]. The total sesame production cultivated area and productivity in Ethiopia during 2012 was 337,505 ha, 44,783tons and 0.73ton/ha respectively (FAOSTAT, 2013).

The major challenges in sesame production are susceptibility to biotic and abiotic stresses, likes insect pests and diseases; drought and soil fertility respectively [5]. Likewise, sesame productivity is very low in Ethiopia due to traditional production technology such as 
broadcasting, poor soil fertility management, recurrent droughts, erratic rainfall, and water logging, and harvesting and postharvest losses. However, there are efforts by several stakeholders, farmers, investors and government bodies to improve its productivity and marketability. Sesame Business Network (SBN), a nongovernmental organization for sesame initiative, developed 20 productivity enhancing packages [6]. Among the several the several factors affecting sesame productivity, fertilizer application has been causing a considerable impact on the growth and productivity of the crop. Field experiments have shown that sesame growth and productivity has improved with proper application of nitrogen fertilizer [7,8] in Ethiopia.

In this regard, sesame production has been doubled in the past five years, with potential interest to improve production and productivity, and expanding production and commercialization through modern sesame farming. However, it is important to study the crop improvement and yield enhancement strategies under the existing climatic conditions, improved management practices in the area for improved sesame production and productivity. In arid and semi-arid areas, soil moisture and poor soil nutrient affect crop growth and productivity. Water has been always the most limiting factor [9]. The irregular rainfall pattern, where onset and cessation of rain are not predictable, crop growth and productivity are affected, especially, when soil moisture stress occur at crop critical growth stages. Rainfall variability; late onset and early cessation of rainfall is a recurrent phenomenon in the Humera. Therefore, field experiment was conducted to the performance of sesame under supplementary irrigation and different nitrogen fertilizer rates.

\section{Materials and Research Methodology}

\section{Description of the Study Area}

This experiment was conducted in Western Tigray, in KaftaHumara Woreda which is located $14.263146 \mathrm{~N}$ latitude and 36.627184E longitude; with altitude ranging from 560 to 1849 meter above sea level and land comprising of flat, undulating mountains, hills and valleys (Haile, 2007). The study site is classified as hot-warm semi-arid climate with temperature rising up to $42{ }^{\circ} \mathrm{C}$ from April to June and declines $25-35^{\circ} \mathrm{C}$ from late June to February. The average maximum and minimum temperature of the area is 37 and $20{ }^{\circ} \mathrm{C}$ respectively; and the annual average precipitation is 400 $650 \mathrm{~mm}$ (NMA 2014). The textural class of the experimental site was clay type soil. The soil $\mathrm{pH}$ of the soil ranges from 8.77 to 9.11 from top to the bottom of the top $60 \mathrm{~cm}$ of the soil.

Table 1: Growth parameters of sesame.

\section{Experimental design and procedures}

Field experiment was conducted in 2015 main cropping seasons. The experiment was laid out in Randomized Complete Block Design (RCBD). Each treatment was replicated three times. The spacing between blocks was $1.5 \mathrm{~m}$ and $1 \mathrm{~m}$ between treatments. There were four nitrogen fertilizer rates; $0 \mathrm{~kg} / \mathrm{ha}, 23 \mathrm{~kg} / \mathrm{ha}, 37.5 \mathrm{~kg} /$ ha and $46 \mathrm{~kg} \mathrm{~N} 2 / \mathrm{ha}$ ). Setit-1 was used as a test crop in with spacing $40 \mathrm{~cm}$ between rows and $10 \mathrm{~cm}$ between plants. There were three levels of supplementary irrigation; rain-fed (Io), four irrigation (I4) and six irrigation (I6) applications.

\section{Fertilizer and irrigation application}

Nitrogen fertilizer was applied in the form of Urea (46-0-0) at two splits, first half was applied during sowing, and the second half was applied 30 DAE. After preparing the field for sowing, seeds were sowing by drilling on rows $40 \mathrm{~cm}$ apart. Thinning out was carried out after sesame seedlings grow two to three true leaves to keep spacing between plants $10 \mathrm{~cm}$. Irrigation scheduling and crop water requirement were calculated using the FAO CROPWAT8. Irrigation time was adjusted to be at critical depletion with irrigation application as 'refill to Field Capacity'.

\section{Data collection and analysis}

Soil samples were collected. soil physical and chemical properties were analyzed before sowing. Plant height, number capsules per plant, harvest index (\%), aboveground biomass (kg/ ha) and grain yield (kg/ha) were recorded. Five plants were taken randomly to record plant height, number of primary branches, number of capsules per plant. Data collected from different treatments were subjected to analysis of variance (ANOVA). Mean comparison $(\mathrm{p}<0.05)$ of each parameter was carried out using SAS 9.0 software. Harvest index was computed as the ratio of grain yield to aboveground biomass.

\section{Result and Discussion}

Mean comparisons for plant height, fruit bearing zone, number of capsules per plant, number of seeds per capsule, thousand grain weight, aboveground biomass, harvest index and grain yield of sesame are presented in Table 1 and Table 2. The ANOVA revealed that there was no interaction effect between supplementary irrigation and nitrogen fertilizer rate. Therefore, results on different crop parameters are presented separately as main effects.

\begin{tabular}{|c|c|c|c|}
\hline \multirow{2}{*}{ Treatment } & PH & No. Capsules Per Plant & No. Branches Per Plant \\
\hline $0 \mathrm{~kg} / \mathrm{ha}$ & $69.31 \mathrm{a}$ & $20.38 \mathrm{a}$ & $1.43 \mathrm{a}$ \\
\hline $23 \mathrm{~kg} / \mathrm{ha}$ & $71.44 \mathrm{a}$ & $22.43 \mathrm{a}$ & $1.58 \mathrm{a}$ \\
\hline $37.5 \mathrm{~kg} / \mathrm{ha}$ & $69.53 \mathrm{a}$ & $22.13 \mathrm{a}$ & $1.60 \mathrm{a}$ \\
\hline $46 \mathrm{~kg} / \mathrm{ha}$ & $74.49 \mathrm{a}$ & $22.31 \mathrm{a}$ & $1.60 \mathrm{a}$ \\
\hline $\mathrm{Cv}(\%)$ & 6.43 & & \\
\hline
\end{tabular}




\begin{tabular}{|c|c|c|c|}
\hline I0 & $68.87 \mathrm{a}$ & $22.85 \mathrm{a}$ & $1.38 \mathrm{a}$ \\
\hline I4 & $71.93 \mathrm{a}$ & $21.85 \mathrm{a}$ & $1.6 \mathrm{a}$ \\
\hline I6 & $72.80 \mathrm{a}$ & $20.74 \mathrm{a}$ & $1.67 \mathrm{a}$ \\
\hline $\mathrm{Cv}(\%)$ & 6.43 & & \\
\hline
\end{tabular}

$\mathrm{PH}$, plant height; $\mathrm{Cv}$, coefficient of variation; means with same letter are not significantly different.

Table 2: Yield and yield components of sesame under different SI and nitrogen fertilizer levels.

\begin{tabular}{|c|c|c|c|c|}
\hline \multirow{2}{*}{ Trt } & Grain Yield (Kg/ha & No. Grains Per Capsule & Aboveground Biomass (kg/ha) & Harvest Index (\%) \\
\hline $0 \mathrm{~kg} / \mathrm{ha}$ & $309 \mathrm{~b}$ & $42.94 \mathrm{a}$ & $629.8 \mathrm{a}$ & $0.55 \mathrm{a}$ \\
\hline $23 \mathrm{~kg} / \mathrm{ha}$ & $285.2 \mathrm{~b}$ & $48.13 \mathrm{a}$ & $697.6 \mathrm{ab}$ & $0.44 \mathrm{a}$ \\
\hline $37.5 \mathrm{~kg} / \mathrm{ha}$ & $388.7 \mathrm{a}$ & $46.64 \mathrm{a}$ & $724.2 \mathrm{ab}$ & $0.57 \mathrm{a}$ \\
\hline $46 \mathrm{~kg} / \mathrm{ha}$ & $423.4 \mathrm{a}$ & $46.16 \mathrm{a}$ & $920.7 \mathrm{~b}$ & $0.47 \mathrm{a}$ \\
\hline $\mathrm{Cv}(\%)$ & 21.02 & 9.85 & 26.37 & $0.53 \mathrm{a}$ \\
\hline $\mathrm{I} 0$ & $272.8 \mathrm{a}$ & $44.62 \mathrm{a}$ & $587.2 \mathrm{a}$ & $0.45 \mathrm{a}$ \\
\hline $\mathrm{I} 4$ & $329.6 \mathrm{a}$ & $46.29 \mathrm{a}$ & $797 \mathrm{ab}$ & $0.55 \mathrm{a}$ \\
\hline $\mathrm{I} 6$ & $455.4 \mathrm{~b}$ & $44.25 \mathrm{a}$ & $845.1 \mathrm{~b}$ & 26.37 \\
\hline
\end{tabular}

Means connected with same letter are not significantly different $(p<0.05)$.

\section{Plant height}

Application of nitrogen fertilizer and supplementary irrigation did not significantly affected sesame plant height. The highest plant height $74.49 \mathrm{~cm}$ and $72.8 \mathrm{~cm}$ was obtained from application of $46 \mathrm{~kg}$ $\mathrm{N} 2$ /ha and six supplementary irrigation respectively. Whereas, the smallest plant height $68.8 \mathrm{~cm}$ was recorded from the control (rainfed treatment). Results obtained in this experiment are similar to the findings reported by Malik et al. [10], showed that sesame plant height increased from $127.48 \mathrm{~cm}$ to $136.37 \mathrm{~cm}$ with increasing nitrogen fertilizer levels $0 \mathrm{~kg} \mathrm{~N} /$ ha to $80 \mathrm{~kg} \mathrm{~N} /$ ha respectively. Similarly, Haruna [11] reported that sesame plant height increased from $85.48 \mathrm{~cm}$ to $116.73 \mathrm{~cm}$ with increasing nitrogen fertilizer rates from $0 \mathrm{~kg}$ to $100 \mathrm{~kg} \mathrm{~N} /$ ha respectively. Sesame plant height increased $72.09,91.5$ and $112.2 \mathrm{~cm}$, with increasing nitrogen fertilizer rates $0 \mathrm{~kg}, 40 \mathrm{~kg}$ and $60 \mathrm{~kg} \mathrm{~N} / \mathrm{ha}$ respectively, while decreasing at $100 \mathrm{~kg} \mathrm{~N} /$ ha [12]; which enriches the evidence observed in this experiment.

\section{Number of capsules per plant}

The highest number of capsules per plant 31.56 recorded from Humera-1 was significantly different $(\mathrm{p}<0.05)$ from the smallest number of capsules per plant 24.25 recorded from Setit-1; however, number of capsules 27.62 recorded from Setit- 2 was not significantly different $(\mathrm{p}<0.05)$ from the number of capsules obtained from Setit-1. Shehu et al. [13], stated that number of capsules per plant was affected by application of nitrogen fertilizer rates, which number of capsules increased from 19.78 to 29.37 with increasing nitrogen fertilizer rates from $0 \mathrm{~kg}$ to $75 \mathrm{~kg} / \mathrm{ha}$. Number of capsules per plant reported by Malik et al. [10], 88.55, 92.5 and 97.88 capsules per plant obtained from application of $0 \mathrm{~kg}, 40 \mathrm{~kg}$ and $80 \mathrm{~kg} \mathrm{~N} / \mathrm{ha}$; which are higher than the results presented in this experiment, probably due to agro-ecological and genetic factors. Haruna [11] reported that highest number of capsules per plant 83.80 was recorded from application of $50 \mathrm{~kg} \mathrm{~N} / \mathrm{ha}$, which higher than the results obtained in this experiment [14-16].

\section{Grain yield}

However, there was no significant difference $(\mathrm{p}<0.05)$ on grain yield obtained from 23 and $46 \mathrm{~kg} \mathrm{~N} / \mathrm{ha}$, and $46 \mathrm{~kg}$ and $69 \mathrm{~kg} \mathrm{~N} / \mathrm{ha}$. Similarly, there was no significant difference $(\mathrm{p}<0.05)$ on grain yield among the three sesame varieties [17-19]. The average grain yield recorded from Setit-1, Setit-2 and Humera-1 was 1124.2, 1099.5 and $1424.0 \mathrm{~kg} /$ ha respectively. According to Mekonnen et al. [8], the highest sesame grain yield was recorded from Barsan 2.08 ton/ha through application of $46 \mathrm{~kg} \mathrm{~N} / \mathrm{ha}$, which is slightly higher than the maximum grain yield obtained from Setit-1 through application of $46 \mathrm{~kg} \mathrm{~N} /$ ha. Field experiment reported by Mekonnen et al. [8] indicated that thousand grain weight of sesame varieties (Adi, Barsan and Mehado-80) was increasing with increasing nitrogen fertilizer up to $69 \mathrm{~kg} \mathrm{~N} /$ ha; while decreasing with $92 \mathrm{~kg} \mathrm{~N} /$ ha. according to Mekonnen et al. [8], the smallest thousand grain weight $2.23 \mathrm{~g}$ obtained from Adi with application of $0 \mathrm{~kg} \mathrm{~N} / \mathrm{ha}$, and the highest thousand grain weight 4.23g recorded from Barsan with application of $46 \mathrm{~kg} \mathrm{~N} / \mathrm{ha}$. According to Malik et al. [10], thousand grain weight increased with increasing nitrogen fertilizer, which highest thousand grain weight 3.42gram recorded from application of $80 \mathrm{~kg} \mathrm{~N} /$ ha was significantly $(\mathrm{p}<0.05)$ higher than the lowest thousand grain weight obtained from the control $(0 \mathrm{~kg} \mathrm{~N} / \mathrm{ha})$ is similar to the results obtained in this experiment. 


\section{Aboveground biomass (kg/ha)}

Aboveground biomass was relatively higher in 2016 than the aboveground biomass obtained in 2017 from the same nitrogen levels (0, 23 and 46kg/ha) and same variety (Setit-1); which might be due to the higher rainfall (distribution and amount) in 2016. Aboveground biomass reported by Mekonnen et al. [8] recorded from three sesame varieties (Adi, Barsan and mehado-80) of same nitrogen fertilizer rates $(0,23$ and $46 \mathrm{~kg} \mathrm{~N} / \mathrm{ha})$ were higher than the results obtained in these experiments with increasing trend with increasing nitrogen fertilizer rates.

\section{Harvest index}

In this experiment, sesame harvest index was not significantly $(\mathrm{p}<0.05)$ affected by application of nitrogen and supplementary irrigation. Sesame harvest indices ranging $27 \%$ to $50 \%$ in these field experiments are relatively higher the harvest index reported by Mekonnen et al. [8] from field experiment conducted in Gode in Somalia Eastern Ethiopia, under irrigation conditions.

\section{Conclusion}

Sesame grain yield and aboveground biomass were significantly $(\mathrm{p}<0.05)$ affected by application of nitrogen fertilizer and supplementary irrigation. The highest grain yield $455 \mathrm{~kg} /$ ha was obtained from application six supplementary irrigation applications; followed by $423.4 \mathrm{~kg} / \mathrm{ha}$ from application of $46 \mathrm{~kg}$ nitrogen per hectare. From this experiment, it can be can be concluded that application of supplementary irrigation can be an important climate change adaptation strategy in areas where late onset and early cessation of rain occur. Besides, application of nitrogen fertilizer under rain-fed condition, accompanied with supplementary irrigation improved sesame productivity.

\section{Acknowledgement}

The author would like to thank the Ethiopian Institute of Agricultural Research for supporting this experiment financially. The author would also like to thank Humera agricultural research center staffs for supporting this experiment.

\section{References}

1. Reddy S (2006) Agronomy of field crops. Kalyani Publishers, New Delhi.

2. Sheahan CM (2014) Plant Guide for Sesame (Sesamum orientale). USDANatural Resource Conservation Service. NJ: Cape May Plant Materials Center, Cape May, New Jersey, USA.

3. Terefe G, Wakjira A, Berhe M, Tadesse H (2012) Sesame production manual. EAIR.
4. Abera H (2009) Analysis of sesame production, supply, demand and marketing issues in Ethiopia. Ethiopia Commedity Exchange Authority, Addis Abeba, Ethiopia.

5. Islam F, Gill RA, Ali B, Farooq MA, Xu L, et al. (2016) Sesame. In SK Gupta (Ed.), Breeding Oilseed Crops for Sustainable Production: Opportunities and Constraints, Elsevier, Amsterdam, Netherlands.

6. SBN (2015) Sesame Business Network (SBN) Newsletter.

7. Umata HB, Dabalo AH (2017) Effect of fertilizer rate on the yield and yield components of sesame (Sesamum indicum) in moisture stress of Eastern Harerghe zone. Agricultural Research and Technology 8(3): 1-7.

8. Mekonnen SB, Sharma JJ, Dechassa N (2016) Effects of nitrogen fertilizer rates on yield and yield components of sesame (Sesamum indicum L.) varieties under irrigation in gode, South-Eastern Ethiopia. International Journal of Plant Breeding and Crop Science 3(1): 71-78.

9. FAO (2012) Climate change adaptation and mitigation; Challenges and opportunities in the food sector, Rome, Italy.

10. Malik MA, Saleem MF, Cheema MA, Ahmed S (2003) Influence of different nitrogen levels on productivity of sesame (Sesamum indicum L.) under varying planting patterns. International Journal of Agriculture and Biology 5(4): 490-492.

11. Haruna IM (2011) Growth and yield of sesame (Sesamum indicum L.) as influenced by nitrogen and intra row spacing in Lafia, Nasarawa State of Nigeria. Elixir International Journal 41: 5685-5688.

12. Shilpi S, Islam MN, Sutradhar GN, Husna A, Akter F (2012) Effect of nitrogen and sulfur on the growth and yield of sesame. International Journal of Bio-Resources and Stress Management 3(2): 177-182.

13. Shehu HE, Kwari JD, Sandabe MK (2009) Nitrogen, phosphorus and potassium nutrition of sesame (Sesamum indicum L.) in Mubi, Nigeria. Research Journal of Agronomy 3(3-4): 32-36.

14.AOAC (2011) Official methods of anayltical chemist (18 $8^{\text {th }}$ edn), AOAC International, USA.

15. CSA (2016) Area and production of major crops. Agricultural Sample Survey (Volume 1), Central Statistical Agency, Addis Abeba, Ethiopia.

16. Elleuch M, Bedigian D, Zitoun A (2011) Sesame (Sesamum indicum L.) Seeds in Food, Nutrition and Health. In VR Preedy, RR Watson, VB Patel (Eds.), Nuts and Seeds in Health and Diseases Prevention, London, Burlington, San Diego, California, USA, pp.1029-1036.

17. Brenna FR, Mason MG, Walton H (2000) Effect of nitrogen fertilizer on the concentrations of oil and protein in canola (Brassica napus) Seed. Journal of Plant Nutrition 23(3): 339-348.

18. Narits L (2010) Effect of nitrogen rate and application time to yield and quality of winter oilseed rape Brassica napus L. var. Oleifera subvar. biennis). Agronomy Research 8(3): 671-686.

19. Smith M (2000) The application of climatic data for planning and management of sustainable rainfed and irrigated crop production. Agricultural and Forest Meteorology 103(1-2): 99-108. 